\title{
SPACES OCCUPIED BY THE EXPANSION OF DRY CLIMATES IN SOUTH AMERICA DURING THE QUATERNARY ICE AGES
}

\section{Aziz Nacib AB'SABER}

(Originally published in Paleoclimas 3, 1977, Instituto de Geografia - Universidade de São Paulo, as Espaços ocupados pela expansão dos climas secos na América do Sul por ocasião dos períodos glaciais quaternários. Translated by P.E. Vanzolini, revised by Thomas R. Fairchild.)

At a time when new outlines are drawn of phytogeographic regions and morphoclimatic domains of South America, one feels called to fathom the recent past, in search of the paleogeographic and paleoecologic frameworks that succeeded each other within the continent during the Quaternary.

There are no major problems of paleospaces, except perhaps in the platform of southern Argentina and in the coastal areas subject to glacioeustatic movements; the present topographic framework may be taken as adequate, especially on the scale of mapping. Interferences of neotectonics, epeirogenesis and continental flexures, although relevant to the study of specific areas, will not be considered in this first approach. The present summary is focused on the approximate identification of the paleo-spaces occupied by dry climates in South America during the latest glacial and glacio-eustatic periods of the Quaternary. In other words we aim at understanding the paths of penetration of dry climates that were associated with a generalized lowering of temperature, consequent upon glaciation, glacio-eustatic movements and the action of cold currents that brought aridity northward. We shall not discuss short, later dry phases related to the optimum climaticum, when there were incidental spots of dry climates, due, among other causes, to global warming and to events of local topographic compartmentation.

Geomorphological, sedimentological and phytogeographic research, performed during the last twenty years [i.e., from 1951 to 1971], make it possible to assert that between the Late Pliocene and the Pleistocene at the time of the main phase of Andean uplift, there were alternations in the distribution of soils and floras over relatively short periods of geological time.

As for the complex mechanisms of retraction and expansion of the plant cover over the fundamental space we have only fragmentary information and indirect inferences.
It is certain that at the beginning of the typical Quaternary climatic variations there were aggressive changes in morphogenetic processes, broad and radical enough, in some areas, to erase the landscapes established during the Late Tertiary and to make possible the spread of new types of plant cover and new physiographic and ecologic fabrics. During the Quaternary, periods of rhexistasy always succeeded periods of biostasy (ERHART, 1955); long-lasting morphoclimatic systems alternated with periods of fast degradation through short-lived, morphogenetically very active transitional periods. However, to be frank, we know very little about these changes of pace of erosive processes, except that they actually paved the way for broader and more general ecological changes of regional scope.

The criteria that have permitted this first synthetic approach to the morphoclimatic and phytogeographic mosaic of the last dry period, 18,000-12,000 years BP (Würm-Wisconsin) belong to the field of multiple and correlated observations. (FIGURE 1). Our summary is supported by a superposition of geomorphological, sedimentological and ecologic facts. We use information accumulated in the literature on geomorphological features (pediments, fluvial terraces, residual bolsones), correlative deposits (detritic formations, terrace deposits, piedmont deposits, stone lines, paleosols), laterites and significant mini-enclaves (evidence of rocky aridity, local cactus fields, refuges of flora and fauna). The largest part of the documentation related to the last Quaternary dry period $(18,000-12,000$ years BP) was taken from data on the superficial structure of landscapes, including a review of personal observations made over a period of many years.

We have paid special attention to the mini-enclaves of residual xerophytic vegetation, that locally resisted the changes to general moister climates that occurred in the last 12,000 years. Up to a certain point, the group of mini-enclaves of xerophytic vegetation seems to indicate the main 


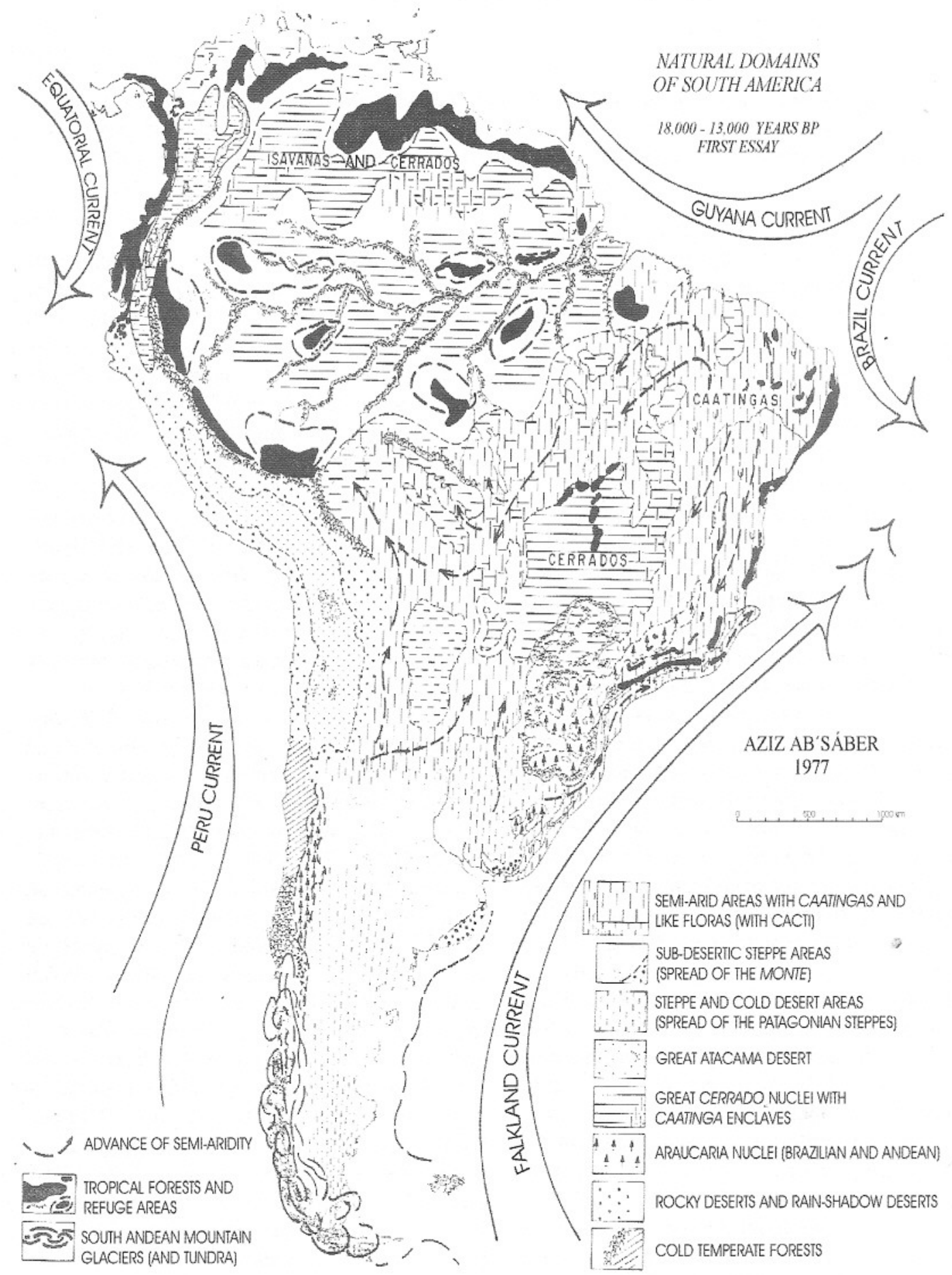

FIGURE 1 - Natural domains of South America in last dry period (18,000 - 13,000 years BP) 
axes of the great routes of penetration of Quaternary semi-aridity in the present space of Tropical America.

The earliest significant discoveries regarding paleoclimates of eastern South America were made by CAILLEUX \& TRICART (1957) and by TRICART (1958). The direct association between glacial conditions, low sea levels and the spread of semi-aridity is attributed to BIGARELLA \& AB'SÁBER (1961) within a framework of correlations nowadays little known. In order to construct this scheme, field observations by BIGARELLA \& AB'SÁBER $(1961,1964)$ and BIGARELLA, MARQUES FILHO \& AB'SÁBER (1961) on gemorphological features and correlative deposits were fundamental. The pediments and correlative deposits at the foot of the Serra de Iqueririm at Garuva, Santa Catarina, furnished full confirmation of the role of semi-arid morphoclimatic Quaternary processes linked to periods of low sea level corresponding to glacial periods.

Based on early findings (1964), some of us thought that the only explanation for the coastal expansion of the Pleistocene dry system should have been a strong activation and advance of the cold Atlantic current northward along eastern South America into tropical latitudes. This idea was supported by the ensemble of conditions at Cabo Frio, where cold upwelling has produced a sub-humid climate with mini-enclaves of xerophytic vegetation on the continent and nearby islands. It was, however, merely a hypothesis, difficult to prove.

In 1970 DAMUTH \& FAIRBRIDGE published a fundamental paper on Quaternary dry climate deposits on the Brazilian coast, based on a very well-conducted research on arkoses deposited on the Brazilian platform. One of the authors, Rhodes Fairbridge, before finishing the article, came to southern Brazil (where he was assisted by Bigarella) in order to check in situ the validity of the observations accumulated in the Brazilian literature. In the paper by DAMUTH \& FAIRBRIDGE (1970) there is an integrated paleoclimatic interpretation, to us the first attempt at a global explanation of the driving forces behind the aridity penecontemporaneous with glacial periods and low sea levels of South America as a whole. More than that, the authors presented schematic maps of the probable course of the cold currents during glacial and interglacial episodes (FIGURE 2). In this way the two schemes of climatic predominance were defined, one corresponding to drier and colder climates during the glacial periods, and the other to warmer and more humid climates during the interglacials. This scheme is valid for a large portion of the geographic space of South America, apparently in direct opposition to what was known in Africa about pluvial and interpluvial periods.

The discovery of the general dynamics and the basic correlations of glaciation and spread of semi-aridity clearly did not exhaust the subject of Quaternary paleoclimates in Brazil nor in South America in general. Much remains to be detailed regarding evolution in time and, especially, in space. Such an interdisciplinary effort is still due.

During the period of glaciation and extended eastern cold currents, within the context of South America, open formations of diverse types predominated over the great forested areas. Nevertheless, one should avoid a mental picture of homogeneous undifferentiated dry climates. On the contrary, everything leads to the concept of a complex map, closely linked to the conditions of topographic compartmentation of the Brazilian plateau and of the central South American depressions, as well as to the numerous small glacial centers and periglacial areas in the Andes.

Caatingas were much more widespread than believed a short time ago (TRICART, 1958). They penetrated numerous inner compartments of the present Brazilian intertropical plateaus in areas now covered by forests or cerrados. Cerrados, cerradões and associated types of vegetation broadly penetrated eastern and central Amazonia, perhaps joining similar areas, now of reduced extent, in Roraima, the Guianas and the Orinoco llanos. In the space of Amazonian lowlands forest refuges remained only in the islands of moisture on some exposed slopes of small ridges and partially convex hills and perhaps also on the westsouthwest arch of the Andean slopes and the northern facade of the Guianas. The existence of these refuges, now engulfed by the expansion and coalescence of the Amazonia-Guianan forests, has received confirmation from the multidisciplinary collaboration of geographers, zoologists and botanists (Haffer, Vanzolini, Williams, Journaux, Prance, Brown, among others).

Only the domain of the cerrados on the central plateau partially resisted the expansion of the dry climates; in the peripheral and interplateau depressions it gave way to caatingas (in depressions between the chapadões of the Urucuia and the central Goiás Plateau; depressed areas north of Brasilia and Anapolis; pediplain of 
Cuiabá; pediplain of the Upper Araguaia; monoclinal intra-chapadões depressions) (Editor's note: chapadões, plateaus with complex structure or table-like rolling plateaus). Thus a belt of caatingas remained intercalated between the main remnants of the core cerrados and the southern and southeastern Amazonian belt. Between Central Brazil and central Amazonia there was an ensemble of very broad bands, made up initially of cerrados, passing into caatingas and returning to cerrados of diverse types. It is possible that at the time the areas of non-xerophytic open formations in Amazonia had greater connections and coalescences with the areas of the present cerrado macro-enclaves of Roraima-Orinoco and the Guianas than with the remaining nucleus in Central Brazil. It is not out of the question to postulate the presence, at certain times in the Late Pleistocene, of caatinga enclaves in several subrocky sectors, otherwise occupied by cerrados and cerradões with elongated gallery forests. Along the same lines, but with less certainty, a plausible area of dry enclaves would be the depression of the Rio Branco grasslands and the low southern slopes of the mountains on the Brazil-Venezuela border.

Everything indicates that during the Quaternary glacial episodes, the core area of the cerrados was much smaller than today. Part of it, on the northern half of the Brazilian Plateau, must have been occupied by caatingas; the southern edge would have been dominated by steppes, mixed prairies and a less dense nucleus of araucaria (southern Mato Grosso and southern plateau). The pediplain of Cuiabá and the interplateau and intermontane depressions of Mato Grosso, Goiás, Bahia and Minas Gerais have always tended toward climates much drier than the present ones. In these areas caatingas predominated over cerrados. On the other hand, in the interior of the inner São Paulo plateaus with the exception of the interplateau and intermontane depressions - cerrados must have prevailed over forests. In the depressions caatingas must have occurred.

In a nutshell, the spatial image that can be visualized, especially with respect to the last dry period of the Quaternary, is that of a macroenclave of cerrados on the high nucleus of the Central Brazil chapadões. This summit enclave remained isolated in Goiás and Mato Grosso, surrounded by a complex network of landscapes (caatingas to the north, east and west, steppes and prairies to the south and southeast), and included a few forest refuges.

Meanwhile it should be noted that a second large area of cerrados existed on the tabuleiros (E.n.: low sedimentary plateaus, tablelands) and low chapadões of Amazonia, with great gallery forests and multiple sub-xerophytic enclaves (caatingas). It is not impossible that this Amazonian network of cerrados occupied a larger area than the central core of summit cerrados. The open formation depressions of the Rio Branco were much drier than nowadays, and the cerrados extended through northwestern Amazonia to the Orinoco.

It is practically certain that no depression, whether denudational (peripheral or monoclinal depression) or tectonic (as in the middle valley of the Paraíba), failed to suffer the penetration of nonhomogeneous, dry climates, originating from one of the two main areas of principal expansion of the Pleistocene semi-aridity, coupled with the glacial system: the enlarged northeastern area and the northernly extended coastal area.

On the east-central part of the continent only the domain of the cerrados on the Central Brazilian plateau partially resisted the encroachment of dry climates and the retraction of the main areas of great tropical forests. We believe that in many areas, especially along the eastern and northern margin of the domain of the cerrados, cerrados and caatingas may have continued to occupy the same space in Central Brazil, in a manner similar to a restricted pattern, at present much reduced in area, that occurs in north-central Bahia in the region of Ribeira do Pombal. Another possibility is a scheme like those found in the Chapada do Araripe or on the southcentral part of the Chapada da Ibiapaba.

It is important to note that at the time of maximum spread of the open formations associated with dry climates or with sub-humid tropical climates having two seasons (i.e. at the time of the glacial maximum) there was an inversion of the scheme of core areas surrounded by heterogeneous transition and contact belts. There prevailed instead a scheme of vast transitional areas. Forests were reduced to refuges quartered in propitious topographic situations. The refuges were fundamentally orographic forests, favorably situated in places where moisture could collect: "brejos", as they are called in the Northeast, islands of moisture and enclaves (BIROT 1957). The refuges on the Serra do Mar, from São Paulo in the south to Espirito Santo in the north, 


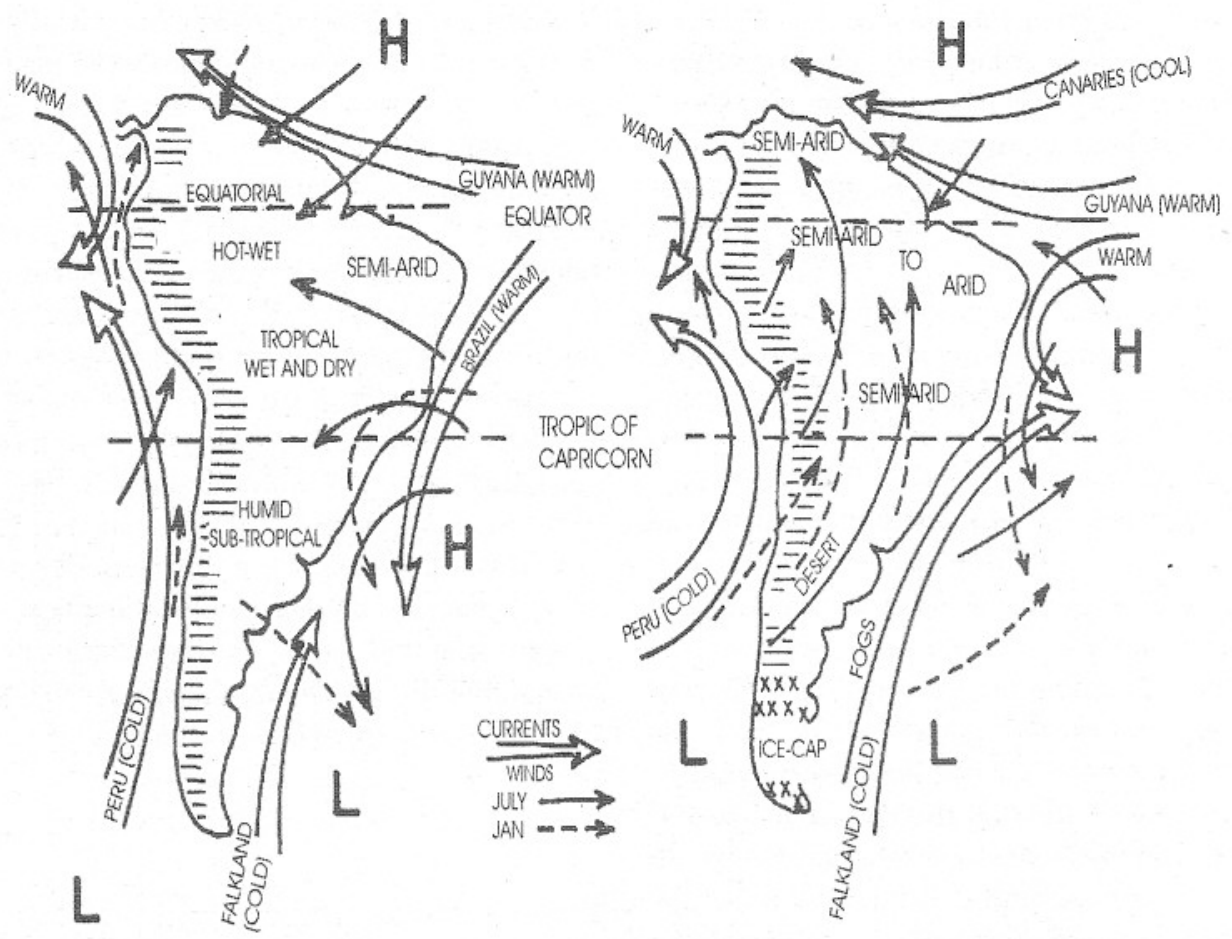

FIGURE 2 - Generalized distribution of ocean currents and wind systems (left) for the present and previous warm interglacial phases and (right) postulated for Pleistocene glacial phases (after DAMUTH \& FAIRBRIDGE, 1970).

must have occupied discontinuous areas on the summits of the scarps most exposed to moisture from the sea; the coastal lowlands were relatively dry.

Some areas of subtropical and even tropical plateaus on the south-central half of the Brazilian Plateau were certainly drier and slightly cooler. Such combinations of aridity and low temperatures would have facilitated the northward extension of the araucarias, as "bridges" along the highlands of eastern Brazil and the eastern midslopes of the Andes. Xerophytic, sub-xerophytic and sub-tropical types of vegetation of the Argentinian north and northwest advanced very deep into the interior of central South American depressions and certain sectors of east-central Brazil.

Going from south to north, things happened by ever more complex and radical changes. At the time of lower (and receding) sea levels, when the southern cone was much less funnel-shaped, its dry areas must have been much more extensive. The glaciers of southern Chile extended to the present day area of the finger lakes of Argentina. Glacial climates and wide belts of cold deserts and peri-glacial areas stimulated mechanical morphogenesis in high and middlehigh areas, favoring the elaboration of great masses of angular and rounded pebbles. Tundras and cold deserts must have existed in the place of today's semi-desertic steppes. Part of the fjords were filled by the same glaciers that had excavated them during syncopated glacial episodes.

Cold currents, much broader, somewhat displaced from their present axes and climatically active, hit in full the coast of southern Brazil and, to a considerable extent, also those of eastern and southeastern Brasil. Only the Serra Geral, in its east-west stretch in Rio Grande do Sul, comprised a barrier high enough to trap moisture, bringing rain to its middle and upper slopes. While the area of the Argentinian and Uruguayan humid pampas was arid, dry and steppe-like, at several times in the Quaternary, the greatest part of the coxilhas (E.n: low rounded hills typical of the rolling topography of southernmost Brazil) of Uruguay and Rio Grande do Sul was under the influence of dry climates and was partially invaded by xerophytic formations with cacti. At the time, there were no subtropical gallery forests in the present areas of mixed prairies in Rio Grande do Sul.

It may be asserted that the drier and colder phases of the Quaternary favored the predominance of Argentinian monte with cacti and 
steppes of northern Patagonian type, with a decrease in the area of humid prairie landscapes. Monte landscape was present in Rio Grande do Sul, and Patagonian steppes entered deeply into the present-day area of humid pampas. Instead of a core area of humid pampas there was a series of refuges and refuge clusters on the humid and subhumid topographically prominent slopes of the pampas of Argentina, Uruguay and Rio Grande do Sul (Sierras del Tandil and de la Ventana, Sierras de Córdoba, hills of the Uruguay-Rio Grande do Sul nucleus of the Brazilian Shield). Based on knowledge of the superficial structure of the landscape of the plateaus of Lajes and Vacaria, we have reason to think that southern Brazilian domain of the araucaria was less compact and continuous, interspersed with subrocky, dry, steppe-like sectors; the domain was additionally somewhat displaced northward in elongated belts following sub-humid and humid ridges and summits (Paranapiacaba, Campos do Jordão, Bocaina, south-central Minas Gerais, southern Serra do Espinhaço). The retreat of the cold currents to their present position, beginning some 10,000-8,000 years ago, would have been accompanied by extensive humidification, with increased density of the araucaria forest, expansion of high prairies in sites of former steppes, and tropicalization of the plateaus of São Paulo and northern Paraná, thereby interrupting the connection between the core-area of the araucarias and outlying refuges on the highlands of southeastern Brazil. The remains of araucaria at Paranapiacaba, near the city of São Paulo and at Bragança Paulista, intermixed with tropical forests of the plateau, would constitute the last residual document of the expansion and coalescence of the tropical forests in São Paulo in a landscape previously similar to that of the São Paulo-Paraná border (Paranaguá Plateau, Upper Ribeira basin on the Paraná side).

Many questions remain open on the paleoclimatic and paleoecological settings of the Andean macro-region. Possibly all the equatorial area of the Andes has been subject to altitudinally progressive temperature lowering; the western lowlands may have been less humid. On the Amazonian slopes it is possible to conceive of discontinuous forest refuges, with predominance of a scheme still observed in the areas of contact between forested hillslopes and the Orinoco savannas in Colombia and Venezuela.

In spite of these preliminary inferences it is still too early, as mentioned previously, to try to reconstruct the mosaic of Quaternary landscapes and floras in terms of a reference cartographic document. What can be done at present, expeditiously and with little risk of distortion, is to sketch a rough outline of the main routes of penetration of the dry climate open formations into the areas that at present constitute great forested domains. In other words, it is only possible to map the areas more habitually visited by the predominantly dry (but never homogeneous) systems that several times during the Quaternary invaded the space at present dominated by tropical systems. It is practically certain that during most of the glacial and glacio-eustatic phases such compartmented (complex mosaics) dry belts substituted predominantly humid systems similar to those found nowadays on the continent.

\section{BIBLIOGRAPHY}

I. Present landscape (overviews)

AB'SÁBER, A.N.1971. A organização natural das paisagens inter e subtropicais brasileiras. In: M. G. Ferri (coord), III Simpósio sobre o Cerrado, Editora Edgard Blücher, São Paulo, p. 1-14.

CABRERA, A.L. \& WILLINK, A. 1973. Biogeografia de America Latina. Prog. Reg. Des. Cient. Tecnologico, OEA, Washington, p.1-120.

EITEN, G. 1974. An outline of the Vegetation of South America. In: Symp. Intern. Primat. Soc., 5, p.529 -545.

HUECK, K. 1966. Die Waelder Südamerikas. Gustav Fischer Verlag, Stuttgart. [Tradução: H. Reichardt, 1972. As florestas da América do Sul. Editora da Universidade de Brasília e Editora Polígono S. A., São Paulo, 466 p.].

HUECK, K. \& SEIBERT, P. 1972. Vegetationskarte von Südamerika. Mapa de Vegetación de America del Sur. Gustav Fischer Verlag, Stuttgart.

II. Palaeoclimates and palaeoclimatology (general works)

AB'SÁBER, A.N. 1958. Conhecimentos sobre as flutuações climáticas do Quaternário no Brasil. Notícia Geomorfológica, 1 (1): 2430.

1962. Revisão dos conhecimentos sobre o ho- 
rizonte sub-superficial de cascalhos inhumados do Brasil Oriental. Universidade do Paraná, Instituto de Geologia 31 p. (Boletim da Universidade do Paraná, Geografia Física, 2).

BIGARELLA, J.J. 1964. Variações climáticas no Quaternário e suas implicações no revestimento florístico do Paraná. Boletim Paranaense de Geografia, (10/15): 211231.

-; AB'SÁBER, A.N. 1961. Quadro provisório dos fatos sedimentológicos, morfoclimáticos e paleoclimáticos na Serra do Mar paranaense e catarinense. In: J.J.Bigarella, P.L.Marques Filho \& Ab'Sáber, Ocorrência de pedimentos remanescentes nas fraldas da Serra do Iquererim (Garuva, SC), Boletim Paranaense de Geografia, (4/5): 91.

-- -- 1964. Pälaeogeographische und Palaeoklimatische Aspekte des Kainozoikum in Südbrasilien. Zeitschrift für Geomorphologie, N. F. 8 (3): 286-312.

-; BECKER, R. (eds). 1975. International Symposium on the Quaternary. In: Boletim Paranaense de Geociências, (33): 370 p.

—; MARQUES FILHO, P.L.; AB'SÁBER, A.N. 1961. Ocorrência de pedimentos remanescentes nas fraldas da Serra do Iquererim (Garuva, SC). Boletim Paranaense de Geografia, (4/5): 82-93.

BIROT, P. 1957. Esquisse morphologique de la région littorale de I'État de Rio Janeiro. Annales de Géographie, 66 (353):80-91.

BROWN Jr., K. S. 1976. Geographical patterns of evolution in Neotropical Lepidoptera. J. Ent. B., 44: 201-242.

CAILLEUX, A. \& TRICART, J. 1957. Zones phytogéographiques et morphoclimatiques du Quaternaire du Brésil. C. R. Soc. de Biogéographie, 293: 7-13.

DAMUTH, J. E. \& FAIRBRIDGE, R. W. 1970. Equatorial Deep-Sea Arkoslc Sands and Ice - Age Aridity in Tropical South America. Bulletin of the Geological Society of America, 81:189-206.

ENJALBERT, H. (s.d.). La Pampa argentin et le Chaco argentin. (Mimeogr., Inédito).
FAIRBRIDGE, R. W. 1962. World sea level and climatic changes. Quaternaria, 6:111-134.

GATES, W. L. 1976. Modeling the Ice-age climate. Science, 191(4232):1138-1144.

HAFFER, J. 1969. Speciation in Amazonian forest birds. Science, 165 (3889):131-137.

JOURNAUX, A. 1975. Recherches géomorphologiques en Amazonie brésilienne. Caen: Centre de Géomorphologie de Caen - C.N.R.S., p.915 (Bulletin 20).

LIMA, D. A. 1964. Contribuição à dinâmica da flora do Brasil. Recife: Instituto de Ciências da Terra, Universidade do Recife, Arquivos, (2):15-20.

MAACK, R. 1947 - Breves notícias sobre a geologia dos Estados do Paraná e Santa Catarina. Arquivos de Biologia e Tecnologia, 2: 99-200.

MARTONNE, E. DE. 1935. Problèmes des regions arides sud-americaines. Annales de Géographie, Paris, 44(247):1-27.

MERCER, J. H. 1975. Glacial history of Southern South America since mid-Pliocene time. In: International Symposium on the Quaternary. Boletim Paranaense de Geociências, (33): 57.

MÜLLER, P. 1973. The dispersal centres of terrestrial vertebrates in the Neotropical Realm. End. W. Junk B. V. Publishers, The Hague.

PRANCE, G. T. 1973. Phytogeographic support for the theory of Pleistocene forest refuges in the Amazon Basin, based on evidence from distribution patterns in Caryocaracea, Chrysobalanacea, Dichape talacea and Lecythidaccae. Acta Amazonica, 3:5-28.

TRICART, J. 1958. Division morphoclimatique du Brésil atlantique central. Revue de Géomorphologie Dynamique, 9 (1/2): 122.

— 1960. As zonas morfoclimáticas do Nordeste Brasileiro. Notícia Geomorfológica, 3(6):17-25.

1963. Oscillations et modifications de caractère de Ia zone aride en Afrique et en Amerique latine lors des périodes glaciaires des hautes latitudes. In: UNESCO, Les changements de climat. Zone Aride, p. 415-419 (Publ. 20). 
VANZOLINI, P. E. 1970. Zoologia sistemática, geografia e a origem das espécies. Instituto de Geografia, Universidade de São Pau1o, 56 p. (Série Teses e Monografias, 3).

- 1973. Paleoclimates, reliefs, and species multiplication in equatorial forests. In: B.J. Meggers, E.S. Ayensu, W.D. Duckworth (eds.) Tropical forest ecosystem in Africa and South America: a comparative review. Smithsonian Institution Press, Washington, p. $255-258$

VUILLEUMIER, B. S. 1971. Pleistocene changes in the fauna and flora of South America. Science, 173:771-780.

\section{Endereço do autor:}

Aziz Nacib Ab'Sáber - Instituto de Estudos Avançados - USP, Edifício da Antiga Reitoria, Av. Prof. Luciano Gualberto, Travessa J, 374, Térreo, Cidade Universitária, 05508-900 São Paulo, SP, Brasil. 